\title{
Modulation of DNA methylation and phenotypic switching in Smooth Muscle Cells by the extracellular matrix microenvironment
}

\author{
Jia-Xin Jiang ${ }^{1,3^{*}}$, Karen J Aitken ${ }^{3}$, Tyler P Kirwan ${ }^{3}$, Nicole D Zhang ${ }^{1,3}$, Shuye Pu ${ }^{4}$, Darius J Bägli ${ }^{1,2,3,4}$ \\ From Epigenetics and Chromatin: Interactions and processes \\ Boston, MA, USA. 11-13 March 2013
}

\begin{abstract}
Background
Partial bladder outlet obstruction due to neurogenic bladder or mechanical obstruction is common amongst the population and can cause bladder injury and dysfunction. Bladder Smooth Muscle Cells (BSMCs) undergo phenotypic changes such as hyper-proliferation, de-differentiation and altered expression of integrins and ECM proteins.[1] Extracellular matrix changes are often crucial inciting events for fibroproliferative disease.[2] Epigenetic change, specifically DNA methylation, may be important factors underlying the persistent fibroproliferative phenotype. Previously, damaged matrix (heat-denatured collagen, DNC) induced hyper-proliferation of bladder smooth muscle cells (BSMC) and the phenotype was not reverted upon a return to normal matrix. [3] We examined the dependency of matrix-induced fibroproliferation and SMC phenotype on DNA methyltransferase activity. The cooperativity of matrix with other inciting stimuli (growth factors, hypoxia and strain) associated with bladder obstruction was also examined.
\end{abstract}

\section{Material and methods}

Primary cultures of neonatal rat BSMC (early passage of 0-2) and human BSMC were plated on 12-, 24-well or $10 \mathrm{~cm}$ culture plates that are pre-coated with either type I bovine native collagen (NC) or DNC (heat-denatured $\mathrm{NC}$ ). Hypoxia was induced at $3 \% \mathrm{O}_{2}$ and $5 \% \mathrm{CO}_{2}$ with a balance of $\mathrm{N}_{2}$. Mechanical strain was applied with slow ramping up to a final 5\% elongation over 16 hours. Inhibitors were added 2-3 hours after plating and remained for $48 \mathrm{hrs}$. Cells were fixed, stained for DNA methyltransferase 3A (DNMT3A), $\alpha$-Smooth muscle actin ( $\alpha$-SMA) and other

'Department of Physiology, University of Toronto, Toronto, ON, Canada, M5S 1 A8

Full list of author information is available at the end of the article
SMC differentiation markers. Intensities and cell numbers were analysed on ImageJ Finally, Illumina 450K array of CpG sites was performed on bisulfite converted DNA from human smooth muscle cells on DNC vs. NC.

\section{Results}

DNC exposure significantly increased the translocalization of DNMT3A into the nucleus of BSMC, in contrast to NC cells, which expressed only cytoplasmic DNMT3A. The increase in nuclear expression of DNMT3A was coupled with decreased expression level of $\alpha$-SMA. Hypoxia with DNC increased DNMT3A nuclear expression, but mechanical strain only mildly increased DNMT3A expression. On DNC cultures, AG490 (JAK2/STAT inhibitor) significantly reduced DNMT3A nuclear localization $(\mathrm{P}=0.001)$, without changing $\alpha$-SMA expression and proliferation. Aza-cytidine suppressed hyper-proliferation of BSMCs cultured on DNC without affecting basal proliferation on NC. On damaged matrix, Sonic hedgehog (SHH) upregulated expression of $\alpha$-SMA, but did not alter proliferation. However, $\mathrm{SHH}$ increased absolute levels of both nuclear and cytoplasmic DNMT3A. Followed by rigorous multiple testing, we discovered significant changes in methylation status for 7 genes in the Illumina $450 \mathrm{~K}$ array.

\section{Conclusions}

Matrix exquisitely regulates DNMT3A localization and expression, and influences differentiation in BSMCs exposed to denatured matrix $+/$ - growth factors or $\mathrm{SHH}$. That nuclear expression of DNMT does not always correspond to decreased $\alpha$-SMA expression suggests that DNA methylation may not directly act as a dedifferentiating factor, as it appears to influence both proliferation/ loss of differentiation on DNC as well as differentiation by SHH. Future work will examine how expression of 
other SMC markers is affected by shRNA knockdown of DNMTs.

\section{Author details}

'Department of Physiology, University of Toronto, Toronto, ON, Canada, M5S 1A8. ${ }^{2}$ Department of Urology, Hospital for Sick Children, Toronto, ON,

Canada, M5G 1X8. ${ }^{3}$ Research Institute, Department of Developmental \& Stem Cell Biology Hospital for Sick Children, Toronto, ON, Canada, M5G 1X8.

${ }^{4}$ Centre for Computational Medicine, Hospital for Sick Children, Toronto, ON, Canada, M5G 1X8.

Published: 18 March 2013

\section{References}

1. Aitken KJ, Tolg C, Panchal T, Leslie B, Yu J, Elkelini M, Sabha N, Tse DJ, Lorenzo AJ, Hassouna M: Mammalian target of rapamycin (mTOR) induces proliferation and de-differentiation responses to three coordinate pathophysiologic stimuli (mechanical strain, hypoxia, and extracellular matrix remodeling) in rat bladder smooth muscle. Am J Pathol 2010, 176(1):304-319.

2. Aitken KJ, Bagli DJ: The bladder extracellular matrix. Part II: regenerative applications. Nat Rev Urol 2009, 6(11):612-621.

3. Herz DB, Aitken K, Bagli DJ: Collagen directly stimulates bladder smooth muscle cell growth in vitro: regulation by extracellular regulated mitogen activated protein kinase. J Urol 2003, 170(5):2072-2076.

doi:10.1186/1756-8935-6-S1-P34

Cite this article as: Jiang et al:: Modulation of DNA methylation and phenotypic switching in Smooth Muscle Cells by the extracellular matrix microenvironment. Epigenetics \& Chromatin 2013 6(Suppl 1):P34.

\section{Submit your next manuscript to BioMed Central and take full advantage of:}

- Convenient online submission

- Thorough peer review

- No space constraints or color figure charges

- Immediate publication on acceptance

- Inclusion in PubMed, CAS, Scopus and Google Scholar

- Research which is freely available for redistribution

Submit your manuscript at www.biomedcentral.com/submit
C Biomed Central 